\title{
RELATIONSHIP BETWEEN ENVIRONMENTAL MANUFACTURING PRACTICES AND THEIR COMPETITIVE OUTCOMES
}

\author{
Syed MisbahUddin*, Chowdury M. L. Rahman, Nahian Ismail Chowdhury, \\ Md. Parvez Shaikh, Fayeq Al-Amin \\ Industrial and Production Engineering Department \\ ShahJalal University of Science and Technology, Sylhet, Bangladesh. \\ *Corresponding e-mail:misbah-ipe@sust.edu.
}

\begin{abstract}
In today's competitive market providing products only in low cost and high quality is not enough. Environmental concern in manufacturing is also an important issue now. To attract investors and customers organizations need to practice environmental manufacturing. This study is focused to present the relationships between some specific environmental manufacturing practices and their relative specific competitive outcomes in the important and vast industry of garment's knitting sector in Bangladesh. Although there are several studies on the impact of environmental practices on the organizations outcomes but they are less construable due to many limitations. This study explores the environmental manufacturing practices under two categories pollution prevention and product stewardship and shows their relative competitive outcomes and establishes the relation between them. Based on the surveys and research it is found that some competitive outcomes are positively affected by some of the practices. These findings are believed to motivate the companies to turn towards the green manufacturing.
\end{abstract}

Keywords: ECM, Competitive outcomes, Knitwear, Pollution prevention, Product stewardship.

\section{INTRODUCTION}

One of the important emerging issue of the $21^{\text {st }}$ century is the environmental effect of the consumer product. Every product that is manufactured has its impact on the environment in its life-cycle. Garments products are no exception from it. Previously customer were indifferent to environmental effect of the products but recent activity and awareness regarding environment has led to some zealous customer who considering the effect of their products on the environment. Even the investors and stakeholders are also demanding organizations to become environmentally responsible with their products and processes to promote their products ${ }^{1-3}$. Garment industries and their products can also adopt environmental manufacturing practices. These practices will not only face the environmental issues but can also provide the organization with competitive advantages.

This research focus on apparel industry as it is one of vast and wide industry all over the world and apparel industry has notable number of environmental impacts that occur at different stages of the apparel life cycle (such as yearn manufacturing, knitting, dying, RMG). Various manufacturing stepsof apparel industry require a huge amount of resources like energy, water, oil etc., which is creating huge pressure on the environment. Furthermore, many of these processes release solid and liquid that are harmful to environment.
In the fiscal year 2014-15 Knitwear contributed 12426.79 million USD, growth rate was $51.14 \%$ and the contribution to total RMG export was $23.49 \%$ and to national GDP was $15.41 \%{ }^{4}$. That tremendous growth rate and contribution reveals that this sector at the same time consuming huge amount of resources and at the meantime producing a large amount of waste. At present, there are about 3500 knitwear factories in Bangladesh but unfortunately only a small fraction of this number practices green manufacturing. Therefore, it has become an emergency to establish green production ambiance in knitwear manufacturing industries. It has also been discovered that although consumers have become aware of environmental sustainability, the price factor still dominates consumers' purchase decision ${ }^{5}$. As a result, low priced products are being manufactured and sold throughout in a greater extent compared to green products.

As there is a common myth that environmental conscious manufacturing will only result in extra activity and increasing cost so manufacturers are often reluctant to adopt environmental friendly manufacturing practices. But assessing the current states of environment and climate change it is important to be environmentally conscious in every aspect of life that also includes manufacturing of products. Different researchers have used different labels to identify and categorize environmental friendly manufacturing practices. Among them the most common approaches to differentiate 
environmental manufacturing practices are pollution control, pollution prevention and product stewardship ${ }^{1,6}$. Pollution control which trap, treat and dispose pollutant and waste through pollution control equipment is an end-of-pipe practice which incurs no competitive advantage rather it is viewed as costly and nonproductive ${ }^{6}$. So it does not yield any competitive advantage as an environmental manufacturing practices. So this research will mainly focus on the pollution prevention and product stewardship practices, as this study adopt the theoretical framework of Hart ${ }^{1}$ for categorization of environmental manufacturing practices.

Pollution prevention practices classified environmental manufacturing practices tend to mitigate and prevent pollutions and result in lower manufacturing $\operatorname{cost}^{1}$. Production of products requires the use of various kinds of resources such as materials, energy, chemicals etc. throughout the whole production process. The storage and use of these materials and chemicals and the final disposal of wastes generated by the production processes bring about many difficulties. Such difficulties include costs of disposal, waste management and health and safety issues. Pollution prevention provides an effective means of mitigating and eliminating such difficulties through better house-keeping, material substitution, recycling or process innovation ${ }^{7}$.

Whereas pollution prevention is mainly concerned with manufacturing processes and operations the product stewardship takes the concept of environmental manufacturing practices to the entire value chain which includes suppliers, stakeholders, designers, R\&D and market. The main concern of product stewardship is to minimize the use of nonrenewable energy and hazardous material in product development including product development, packaging, material used and overall product lifecycle, considering the environmental impact ${ }^{8}$. Product stewardship practices involve use of sustainable and renewable resources, redesigning products and processes to be more environmentally sustainable. According to Hart ${ }^{1}$, product stewardship can label a company as green company which increase company reputation, which result in attracting new customers. Also redesigning products and processes result in improving the quality of products and promote innovative ideas ${ }^{3}$. Altogether pollution prevention and product stewardship are referred as environmental manufacturing practices that yield to competitive gains.

This study will explore the existing environmental manufacturing practices that are used more or less often in knitwear industry of Bangladesh. In this study industry specific sustainable manufacturing practices (e.g., recycling waste, redesign product etc.) and their relationship or lack thereof with specific competitive manufacturing outcomes (e.g., cost and quality etc.) will be examined. Specific competitive preemption outcomes of company image, innovativeness will also be investigated in the context of environmentally sustainable manufacturing practices.

\section{LITERATURE REVIEW}

There are abundant researches on the environmental manufacturing practices but they tend to be inconclusive. As some studies show that the environmental initiative has negative impact on organizational outcomes ${ }^{9,10}$ while other studies indicate that there do exist some competitive gain with environmental conscious manufacturing ${ }^{1,3,11,12}$. Previous empirical research used general measures for evaluating organizational environmental practices like proxy etc. ${ }^{11,13}$. But these kind of general or aggregated measures tend to give only few insights of environmental manufacturing practices so they have very less value to the practitioners. Because at the operational level they only adopt environmental concern that leads to competitive demands. In additions previous studies focused only on firm level financial performance as outcomes such as profitability and beneficiaries ${ }^{9,10}$. But other researches ${ }^{13}$ suggest that using such general measures may result in inconclusive findings since they do not cover the total effects of environmental practices on the company performance.

There are many study regarding the application of environmental friendly manufacturing practices. Bansal, operationalizes company's environmental sustainability development and examines its organizational determinants ${ }^{6}$. Marshall et al, brought together previous environmental management research regarding individual-level and institutional-level drivers of environmental stewardship to develop a model and series of questions regarding proactive environmental behavior ${ }^{14}$. There are also case studies on the connection between environmental manufacturing practices and organizational performance ${ }^{1,3,15}$. Porter and Linde mentioned that an underlying logic links the environment, resource productivity, innovation, and competitiveness ${ }^{3}$. Shrivastava, in his work explains the concept of 'environmental technologies' as a competitive force and a tool for competitive advantage. Environmental technologies offer a new substantive orientation and a management process for minimizing ecological impacts of economic production while enhancing competitiveness of firms ${ }^{15}$.

Though empirical research on environmental manufacturing practices and competitive outcomes is 
rare. However some recent studies do indicate some connection between the environmental practices and competitive outcomes ${ }^{12,16,17}$. Clelland et al, shows that waste-minimization practices provide immediate environmental and operational benefits and build momentum for further steps toward environmentally sustainable economic development ${ }^{17}$. Klassen et al, found that composition of a plant's portfolio, the pattern of its investment in environmental technologies in manufacturing over time significantly affect both manufacturing and environmental performance for a sample of manufacturing plants ${ }^{12}$. Christman ${ }^{13}$ finds that the use of pollution prevention technologies does not directly contribute to cost advantages; however, complementary assets, including innovation and early timing, are significantly related to cost advantages.

Studies that do not support positive or significant relationships between environmental manufacturing practices and competitive outcomes include ${ }^{11,18}$.Again some studies are somewhat inconclusive as often the measures of outcomes are expressed only in financial measures which is only a part of competitive advantages ${ }^{2,13}$. Naffziger et al, in their survey result indicated positive correlations between level of environmental concern of small business companies and efforts and between their efforts and the effects on their performance (efficiency, profit, and public image $)^{2}$. Nehrt, research results indicated a positive relationship between timing of environmental investments and profit growth ${ }^{18}$. There are also some methodological limitation that lead to the inconclusive result. Sometimes the samples are drawn from diverse industries, where one industry may have positive outcome from one practice but it may not some for another industry ${ }^{13}$. This research tries to avoid these limitations by focusing on only one industry.

\section{METHODOLOGY}

The methodology of this research is designed as follows.

\section{Industry Choice}

Past studies of environmental manufacturing practices and competitive outcomes have often taken their sample from a number of different industries ${ }^{2,16}$, or from one large company that belongs to a relatively small group of industries with products and/or processes that present significant environmental challenges (e.g., chemicals, oil refining, wood/paper pulp, etc. $)^{13}$. Since research on industries such as chemicals, oil refining, and wood/paper pulp is already well established, this work is focused on a less-researched industry. Correspondingly, since some environmental practices tend to be industry specific ${ }^{13}$, this work focuses on knitwear manufacturing industry. Knitwear manufacturing is an important industry to study for several reasons. Knitwear manufacturing has had a long history of heavy resource usage and environmental challenges. Knitwear manufacturers are heavy users of water and energy, and must track and report air and water emissions. In addition, most of the industry is located in or around Dhaka city of Bangladesh, therefore, the industry's production processes affect a large regional population. There are little empirical research available on environmental practices in the Bangladesh knitwear industry.

\section{Theory and Propositions}

This research has adopt the theoretical viewpoints of researchers including Hart ${ }^{1}$ and Porter and van der Linde ${ }^{3}$. An initial list of environmental manufacturing practices with respect to pollution prevention and product stewardship from previous studies ${ }^{1,19}$, have been collected and adapted to knitwear industry. Since some environmental manufacturing practices can be specific to a particular industry $^{13}$, as the list was developed, a search for environmentally sustainable practices was conducted through the web sites of knitwear manufacturers and industry publications. Three factories were also visited for further specifying the sustainable manufacturing practices adopted in Bangladesh. Their manufacturing processes were carefully observed, the measures taken by them as a matter of environmental consciousness were identified. Personnel at higher post such as manager, production engineer were interviewed to find out their practices and their expert opinion was used to list out the more common environmental manufacturing practices that are adoptable from the perspective of knitting industry in Bangladesh. This final list included 16 practices which were classified into pollution prevention and product stewardship practices.

After identifying the pollution prevention and product stewardship practices the competitive outcomes related to them were identified. General proposition about the competitive advantages were developed from the benefits of pollution prevention and product stewardship practices. Some of the proposition are supported by the pollution prevention practices while others are by the product stewardship as some advantages can be specific to some practices.

Pollution prevention practices includes reduction in resources usage and waste and reuse and recycle of defectives. Such practices results in savings in manufacturing $\operatorname{cost}^{1}$, increase productivity, improves employee morale and participation and enhance company reputation ${ }^{3}$. Product stewardship involves environmental practices that extend the environmental perspective to other internal and external stakeholders

Journal of Mechanical Engineering, Vol. ME 48, December 2018

Transaction of the Mechanical Engineering Division, The Institution of Engineers, Bangladesh 
such R\&D, product designers and suppliers. Example of product stewardship practices are redesigning products and processes to be more eco-friendly, using renewable resources and encouraging suppliers to practice pollution prevention and product stewardship. Hart $^{1}$ argues that the major competitive advantage to be gained through product stewardship are competitive preemptions ${ }^{20,21}$. The general preempts are company reputation $^{2}$, liability reduction ${ }^{22}$, increased quality ${ }^{3}$, attract new customers ${ }^{1,23}$, promote innovative ideas ${ }^{3}$. Based on this information following propositions have been developed.

Proposition 1: Environmental manufacturing practices that are classified as pollution prevention practices will tend to decrease manufacturing cost.

Proposition 2: Environmental manufacturing practices that are classified as pollution prevention practices will tend to increase productivity.

Proposition 3: Environmental manufacturing practices that are classified as pollution prevention practices will tend to improve employee morale and participation.

Proposition 4: Environmental manufacturing practices that are classified as pollution prevention practices or product stewardship practices will tend to enhance company reputation.

Proposition 5: Environmental manufacturing practices that are classified as product stewardship practices will tend to reduce liability.

Proposition 6: Environmental manufacturing practices that are classified as product stewardship practices will tend to increase quality.

Proposition 7: Environmental manufacturing practices that are classified as product stewardship practices will tend to attract new customers.

Proposition 8: Environmental manufacturing practices that are classified as product stewardship practices will tend to promote innovative ideas.

\section{SURVEY AND DATA COLLECTION}

For survey, questionnaire was developed that includes the list of all the environmental manufacturing practices and the competitive outcomes based on previous researches and expert opinion described above. Relative importance index (RII) was used in the survey to measure the impact of practices on the outcomes. RII is an established method to measure the impact of factors based on the given importance value ${ }^{24}$. Relative importance index was in the 1 to 5 Likert's scale, 1 indicated no impact, similarly 2 is negligible impact, 3 is marginal impact, 4 is moderate impact and 5 is major impact. RII is calculated using the following equation:

$$
R I I=\frac{\Sigma W}{N \times A}
$$

where $\mathrm{W}=$ weighted given by a respondent, $\mathrm{N}=$ total number of responses, $\mathrm{A}=$ highest weight.

Finally, responses were collected through survey and the number of respondent factories were 46 . Although this number is relatively small to the total number of knitting factories in Bangladesh but there are only around 300 factories use environmental friendly manufacturing ${ }^{25}$ and they also occupy great section in exporting for renowned brand worldwide so for a valid conclusion it was necessary to take data from only those factories. Two methods were applied to get the responses one is online survey and other is by visiting personally. Online survey was adopted to get as many responses as possible to make the deduction valid. Online survey questionnaire was sent directly to the person in each company who was best qualified to respond with respect to environmental practices adopted by the company. Visiting responses were also collected from top level personnel to get the accurate result and as the data were qualitative so it was necessary. Production floors were also observed while visiting for validating the practices. In the preliminary visits and conversations with industry members revealed reluctance to provide quantitative data due to confidential reasons. In addition, conversations with members also revealed that respondents would be much more likely to complete a short survey, so the survey was kept as short as possible. Respondent were asked to give weightage for each outcome corresponding to each practice that they are currently using, if a practice is not in use they were instructed to mention the practice is not in use. Finally, 46 responses from 46 different factories were gathered for analysis.

\section{ANALYSIS AND RESULTS}

Response percentages of pollution prevention practices and product stewardship practices outcomes are aggregated and averaged to find out the relative importance of each practice toward the competitive outcomes. Finally, for an individual outcome, the RII score of each practice averaged and checked whether they support the propositions or not.

\section{Pollution prevention practices}

As indicated in table: 1; pollution prevention practices tend to be used by most respondents in the Bangladesh knit industries. There are 7 pollution prevention practices that include all the outcomes. Pollution prevention practices like reducing raw material usage have got maximum of 0.99 RII score in an outcome that is a major impact. From table-2, it is seen that five out of seven pollution prevention practices have major impact on the reducing manufacturing cost and rest two practices like reducing emission and divert solid waste from landfill have negligible or no impact on this measure. Average 
responded RII score of 0.73 for reduce manufacturing cost indicates that pollution prevention practices help to decrease manufacturing cost significantly. So, the proposition 1 is strongly supported with respect to knit industry.

Productivity is something that doesn't only related to the quantity of production per unit time. Other factors related to company image and cultures are also related to productivity. As shown in table-2, the reported usage of pollution prevention practices classified has no relation to the productivity such as, reducing emission, reducing chemical usage and divert solid waste from landfill. Only two of them got major impact, one of them got marginal impact and one of them got negligible impact. So, on an average the pollution prevention practices have got RII score of 0.52 on the outcome of increase productivity, indicated as marginal impact and thus proposition 2 is not supported.

Table 1: Pollution Prevention Practices Response Percentage

\begin{tabular}{|l|c|c|c|c|c|c|c|c|c|}
\hline \multirow{2}{*}{$\begin{array}{l}\text { Pollution } \\
\text { prevention } \\
\text { practices }\end{array}$} & $\begin{array}{c}\text { Practices } \\
\text { responses } \\
\text { percentage } \\
\text { (n=46) }\end{array}$ & $\begin{array}{c}\text { Reduces } \\
\text { manufactur } \\
\text { ing cost }\end{array}$ & $\begin{array}{c}\text { Increases } \\
\text { productivi } \\
\text { ty }\end{array}$ & $\begin{array}{c}\text { Improves } \\
\text { employee } \\
\text { morale and } \\
\text { participation }\end{array}$ & $\begin{array}{c}\text { Enhances } \\
\text { company } \\
\text { reputation }\end{array}$ & $\begin{array}{c}\text { Reduces } \\
\text { liability }\end{array}$ & $\begin{array}{c}\text { Increases } \\
\text { quality }\end{array}$ & $\begin{array}{c}\text { Attracts } \\
\text { new } \\
\text { customer }\end{array}$ & $\begin{array}{c}\text { Promotes } \\
\text { innovative } \\
\text { ideas }\end{array}$ \\
\hline $\begin{array}{l}\text { Reducing raw } \\
\text { material usage }\end{array}$ & 100.00 & 100.0 & 86.96 & 08.70 & 65.22 & 65.22 & 8.69 & 21.74 & 69.57 \\
\hline $\begin{array}{l}\text { Reducing } \\
\text { emissions }\end{array}$ & 74.00 & 41.17 & 00.00 & 29.41 & 100.0 & 100.0 & 05.89 & 58.82 & 70.59 \\
\hline $\begin{array}{l}\text { Reducing solid } \\
\text { waste }\end{array}$ & 87.00 & 100.0 & 90.00 & 20.00 & 95.00 & 95.00 & 20.00 & 10.00 & 45.00 \\
\hline $\begin{array}{l}\text { Reducing } \\
\text { chemical usage }\end{array}$ & 100.00 & 82.61 & 17.40 & 13.04 & 91.30 & 100.0 & 04.34 & 08.70 & 47.83 \\
\hline $\begin{array}{l}\text { Recycle and } \\
\text { reuse defectives }\end{array}$ & 100.00 & 86.96 & 56.52 & 17.39 & 78.26 & 100.0 & 65.22 & 47.83 & 78.26 \\
\hline $\begin{array}{l}\text { Reduce energy } \\
\text { use }\end{array}$ & 87.00 & 95.00 & 35.00 & 15.00 & 80.00 & 65.00 & 00.00 & 35.00 & 95.00 \\
\hline $\begin{array}{l}\text { Divert solid } \\
\text { waste from } \\
\text { landfill }\end{array}$ & 91.00 & 00.00 & 00.00 & 14.29 & 61.90 & 95.24 & 09.53 & 38.09 & 100.0 \\
\hline
\end{tabular}

Table 2: RII Score of Pollution Prevention Practices

\begin{tabular}{|l|c|c|c|c|c|c|c|c|}
\hline \multirow{2}{*}{$\begin{array}{l}\text { Pollution } \\
\text { prevention } \\
\text { practices }\end{array}$} & \multicolumn{9}{|c|}{ Competitive outcomes (RII Score) } \\
\cline { 2 - 9 } & $\begin{array}{c}\text { Reduces } \\
\text { rinufactu } \\
\text { ring cost }\end{array}$ & $\begin{array}{c}\text { Increases } \\
\text { productivity }\end{array}$ & $\begin{array}{c}\text { Improves } \\
\text { employee morale } \\
\text { and participation }\end{array}$ & $\begin{array}{c}\text { Enhances } \\
\text { company } \\
\text { reputation }\end{array}$ & $\begin{array}{c}\text { Reduces } \\
\text { liability }\end{array}$ & $\begin{array}{c}\text { Increases } \\
\text { quality }\end{array}$ & $\begin{array}{c}\text { Attracts } \\
\text { new } \\
\text { customer }\end{array}$ & $\begin{array}{c}\text { Promotes } \\
\text { innovative } \\
\text { ideas }\end{array}$ \\
\hline $\begin{array}{l}\text { Reducing raw } \\
\text { material usage }\end{array}$ & 0.99 & 0.97 & 0.23 & 0.69 & 0.68 & 0.26 & 0.36 & 0.66 \\
\hline $\begin{array}{l}\text { Reducing } \\
\text { emissions }\end{array}$ & 0.48 & 0.24 & 0.41 & 0.96 & 0.96 & 0.22 & 0.58 & 0.75 \\
\hline $\begin{array}{l}\text { Reducing solid } \\
\text { waste }\end{array}$ & 0.90 & 0.87 & 0.27 & 0.84 & 0.82 & 0.30 & 0.27 & 0.56 \\
\hline $\begin{array}{l}\text { Reducing } \\
\text { chemical usage }\end{array}$ & 0.80 & 0.26 & 0.24 & 0.81 & 0.84 & 0.21 & 0.23 & 0.52 \\
\hline $\begin{array}{l}\text { Recycle and } \\
\text { reuse } \\
\text { defectives }\end{array}$ & 0.83 & 0.63 & 0.33 & 0.72 & 0.90 & 0.73 & 0.57 & 0.76 \\
\hline $\begin{array}{l}\text { Reduce energy } \\
\text { use }\end{array}$ & 0.91 & 0.46 & 0.26 & 0.86 & 0.71 & 0.21 & 0.41 & 0.95 \\
\hline $\begin{array}{l}\text { Divert solid } \\
\text { waste } \\
\text { landfill }\end{array}$ & 0.22 & 0.21 & 0.28 & 0.73 & 0.92 & 0.24 & 0.40 & 0.92 \\
\hline $\begin{array}{l}\text { Cumulative RII } \\
\text { Score }\end{array}$ & 5.13 & 3.64 & 2.02 & 5.61 & 5.83 & 2.17 & 2.82 & 5.12 \\
\hline $\begin{array}{l}\text { Average RII } \\
\text { Score }\end{array}$ & 0.73 & 0.52 & 0.29 & 0.80 & 0.83 & 0.31 & 0.40 & 0.73 \\
\hline
\end{tabular}


Employee morale and participation could be a competitive outcome from pollution prevention practices mentioned in previous studies. The reported usage of these practices like, reducing raw material usage, reducing solid waste, reducing chemical usage and divert solid waste from landfill all four of them have no impact on employee morale and participation from the assessment of RII score. Although two of them got negligible impact on this measure and on an average this outcome has got the RII score of 0.29 as no impact. So, proposition 3 is not supported by the sustainable manufacturing practices as classified in pollution prevention practices.

The pollution prevention and product stewardship both practices help to increase company reputation from lower to a higher extent. In pollution prevention practices six of them showing that there is a major impact on company reputation and one of them has moderate impact on this regard. The average RII score of 0.80 indicates that pollution prevention practices have major impact on enhancing company reputation as shown in table 2 .Among the product stewardship practices as shown in table 4 , four of them have strong impact on company reputation. On an average the assessment shows that, with average RII score of 0.82 delineate that company reputation is increased by the help of both practices and hence proposition 4 is strongly supported.

\section{Product Stewardship Practices}

Table 3, indicates that the reported usage for product stewardship practices ranged from a low of $87 \%$ (R\&D for process and product sustainability, use eco certification, train employees for sustainability practices) to a higher of $100 \%$ (use renewable energy). Reduction of liabilities with the help of sustainability has a great impact on industries. Reducing emission, reducing chemical usage and recycling has profound impact on reducing liabilities over environment. Though reduction of raw material has a moderate impact on reducing liabilities with RII score of 0.68 . On an average RII score of 0.83 , pollution prevention practices support the proposition 5. Though Veroutis et al. ${ }^{22}$, describe liability reduction as an outcome of product stewardship practices but the empirical research shows that, liability reduction is greatly supported by pollution prevention practices. Where the product stewardship practices have an average RII score of 0.38. So, it is found that, the environmental manufacturing practices have a moderate impact on reducing liabilities and hence proposition 5 is supported.

Among the respondents who use the product stewardship practices, few of them responded that these practices increase quality as shown in table 3 .

Table 3: Product Stewardship Practices Response Percentage

\begin{tabular}{|l|c|c|c|c|c|c|c|c|c|}
\hline \multirow{2}{*}{$\begin{array}{l}\text { Product } \\
\text { Stewardship } \\
\text { practices }\end{array}$} & $\begin{array}{c}\text { Practices } \\
\text { responses } \\
\text { percentage } \\
\text { (n=46) }\end{array}$ & $\begin{array}{c}\text { Reduces } \\
\text { manufactu } \\
\text { ring cost }\end{array}$ & $\begin{array}{c}\text { Increases } \\
\text { productiv } \\
\text { ity }\end{array}$ & $\begin{array}{c}\text { Improves } \\
\text { employee } \\
\text { morale and } \\
\text { participation }\end{array}$ & $\begin{array}{c}\text { Enhances } \\
\text { company } \\
\text { reputation }\end{array}$ & $\begin{array}{c}\text { Reduces } \\
\text { liability }\end{array}$ & $\begin{array}{c}\text { Increase } \\
\text { s quality }\end{array}$ & $\begin{array}{c}\text { Attracts } \\
\text { new } \\
\text { customer }\end{array}$ & $\begin{array}{c}\text { Promotes } \\
\text { innovative } \\
\text { ideas }\end{array}$ \\
\hline $\begin{array}{l}\text { Use sustainable } \\
\text { raw materials }\end{array}$ & 96.00 & 27.27 & 13.63 & 18.18 & 100.00 & 45.45 & 31.81 & 86.37 & 90.91 \\
\hline $\begin{array}{l}\text { Use renewable } \\
\text { energy }\end{array}$ & 100.0 & 30.43 & 04.35 & 17.39 & 86.95 & 52.18 & 4.35 & 65.22 & 100.0 \\
\hline $\begin{array}{l}\text { Usage of } \\
\text { eco-friendly } \\
\text { chemical }\end{array}$ & 91.00 & 04.76 & 00.00 & 33.33 & 100.0 & 52.38 & 19.05 & 95.24 & 95.24 \\
\hline $\begin{array}{l}\text { Other tools (e.g. } \\
\text { LCA*, DFE** }\end{array}$ & 91.00 & 14.28 & 09.52 & 23.81 & 90.48 & 04.76 & 14.29 & 100.0 & 71.43 \\
\hline $\begin{array}{l}\text { R\&D for } \\
\text { product } \\
\text { sustainability }\end{array}$ & 87.00 & 15.00 & 30.00 & 45.00 & 50.00 & 10.00 & 70.00 & 90.00 & 100.0 \\
\hline $\begin{array}{l}\text { R\&D for } \\
\text { process } \\
\text { sustainability }\end{array}$ & 87.00 & 15.00 & 30.00 & 55.00 & 60.00 & 15.00 & 55.00 & 90.00 & 100.0 \\
\hline $\begin{array}{l}\text { Use 3rd party } \\
\text { eco certification }\end{array}$ & 87.00 & 05.00 & 00.00 & 50.00 & 100.00 & 15.00 & 10.00 & 65.00 & 05.00 \\
\hline $\begin{array}{l}\text { Train employees } \\
\text { in sustainability }\end{array}$ & 87.00 & 15.00 & 35.00 & 100.0 & 50.00 & 10.00 & 45.00 & 40.00 & 90.00 \\
\hline $\begin{array}{l}\text { Sustainable } \\
\text { education } \\
\text { \&outreach }\end{array}$ & 91.00 & 04.76 & 28.57 & 76.19 & 100.0 & 28.57 & 23.81 & 71.42 & 52.38 \\
\hline
\end{tabular}


From the respondent's point of view, it is found that quality is not increased by sustainable practices. There are some practices which have no impact on increasing quality though $\mathrm{R} \& \mathrm{D}$ for process and product sustainability have marginal and moderate impact on this regard. So, over all RII values of 0.39 specifies that product stewardship practices have little or no impact on increasing quality hence proposition 6 is not supported by the product stewardship practices.

Table 4: RII Score of Product Stewardship Practices

\begin{tabular}{|l|c|c|c|c|c|c|c|c|}
\hline \multirow{2}{*}{$\begin{array}{l}\text { Product } \\
\text { stewardship } \\
\text { practices }\end{array}$} & \multicolumn{7}{|c|}{ Competitive outcomes (RII Score) } \\
\cline { 2 - 8 } & $\begin{array}{c}\text { Reduces } \\
\text { manufactu } \\
\text { ring cost }\end{array}$ & $\begin{array}{c}\text { Increases } \\
\text { productivity }\end{array}$ & $\begin{array}{c}\text { Improves } \\
\text { employee morale } \\
\text { and participation }\end{array}$ & $\begin{array}{c}\text { Enhances } \\
\text { company } \\
\text { reputation }\end{array}$ & $\begin{array}{c}\text { Reduces } \\
\text { liability }\end{array}$ & $\begin{array}{c}\text { Increases } \\
\text { quality }\end{array}$ & $\begin{array}{c}\text { Attracts } \\
\text { new } \\
\text { customer }\end{array}$ & $\begin{array}{c}\text { Promotes } \\
\text { innovative } \\
\text { ideas }\end{array}$ \\
\hline $\begin{array}{l}\text { Use sustainable } \\
\text { raw materials }\end{array}$ & 0.30 & 0.23 & 0.24 & 0.93 & 0.62 & 0.34 & 0.85 & 0.86 \\
\hline $\begin{array}{l}\text { Use renewable } \\
\text { energy }\end{array}$ & 0.28 & 0.22 & 0.27 & 0.86 & 0.64 & 0.23 & 0.64 & 0.91 \\
\hline $\begin{array}{l}\text { Usage } \\
\text { eco-friendly } \\
\text { chemical }\end{array}$ & 0.21 & 0.20 & 0.41 & 0.95 & 0.58 & 0.26 & 0.92 & 0.93 \\
\hline $\begin{array}{l}\text { Other tools (e.g. } \\
\text { LCA*, DFE**) }\end{array}$ & 0.25 & 0.22 & 0.27 & 0.91 & 0.21 & 0.25 & 0.98 & 0.89 \\
\hline $\begin{array}{l}\text { R\&D for product } \\
\text { sustainability }\end{array}$ & 0.27 & 0.34 & 0.44 & 0.59 & 0.22 & 0.68 & 0.91 & 0.95 \\
\hline $\begin{array}{l}\text { R\&D for process } \\
\text { sustainability }\end{array}$ & 0.25 & 0.29 & 0.54 & 0.55 & 0.27 & 0.52 & 0.92 & 0.97 \\
\hline $\begin{array}{l}\text { Use 3rd party eco } \\
\text { certification }\end{array}$ & 0.21 & 0.20 & 0.60 & 0.96 & 0.24 & 0.22 & 0.67 & 0.21 \\
\hline $\begin{array}{l}\text { Train employees } \\
\text { in sustainability }\end{array}$ & 0.24 & 0.45 & 0.97 & 0.64 & 0.22 & 0.63 & 0.54 & 0.93 \\
\hline $\begin{array}{l}\text { Sustainable } \\
\text { education } \\
\text { outreach }\end{array}$ & 0.22 & 0.40 & 0.75 & 0.94 & 0.43 & 0.36 & 0.70 & 0.55 \\
\hline $\begin{array}{l}\text { Cumulative RII } \\
\text { Score }\end{array}$ & 2.23 & 2.55 & 4.49 & 7.33 & 3.43 & 3.49 & 7.13 & 7.20 \\
\hline $\begin{array}{l}\text { Average } \\
\text { Score }\end{array}$ & 0.25 & 0.28 & 0.50 & 0.82 & 0.38 & 0.39 & 0.79 & 0.80 \\
\hline
\end{tabular}

Attracting new customers (internal or external) is the prime strategy of every industries. Though pollution prevention practices have negligible impact with average RII score of 0.40 on this outcome but product stewardship practices have major impact with average RII score of 0.79 on attraction of new customers. Some tools used in product stewardship practices (like Life cycle assessment and Design for environment) have excellently major impact with RII score of 0.98 according to the respondent's assessment. Usage of eco-friendly chemicals, R\&D for process and product sustainability have also some major impact with RII score of upper 0.90 on this outcome. So, average RII score with 0.79 shows that product stewardship practices have a major impact on attracting new customers and thus proposition 7 is supported by product stewardship practices.

Among all the product stewardship practices, usage of renewable energy, $\mathrm{R} \& \mathrm{D}$ for product and process sustainability are the most promising practices that have major impact towards innovation. Though $3^{\text {rd }}$ party's eco-certification has no impact on this outcome. On an average RII score of 0.80 indicates that product stewardship practices have major impact on promoting innovative ideas. So proposition 8 is strongly supported.

Product stewardship practices may be more difficult to successfully coordinate, since they require multifunctional coordination. Since product stewardship practices expand environmentalism to other internal and external stakeholders (besides manufacturing), they tend to require organization-level initiatives for implementation, including support and coordination of multiple stakeholders. For example, redesigning products and processes to improve sustainability requires top-management support for implementation, as well as cooperation from internal and external stakeholders including R\&D, design, purchasing, sales, and suppliers. However, additional empirical research that 
is beyond the scope of this study is necessary to better support this possible explanation.

\section{Ranking the Practices}

RII values of the outcomes under each practice can also be used to rank the practices based on the impact. For this reason, average RII of each practice were calculated and the maximum valued RII practice was ranked first as it indicates that this practice has most impact on the competitive outcomes. Similarly rest of the practices were ranked serially based on the average RII value and this ranking of practices is given in table 5 .

Table 5: Ranking of the practices

\begin{tabular}{|l|l|l|}
\hline Practice name & $\begin{array}{l}\text { Average } \\
\text { RII }\end{array}$ & Rank \\
\hline Recycle and reuse defectives & 0.6838 & 01 \\
\hline Reducing raw material usage & 0.6050 & 02 \\
\hline Reducing solid waste & 0.6038 & 03 \\
\hline Reduce energy use & 0.5963 & 04 \\
\hline $\begin{array}{l}\text { Train in } \\
\text { sustainability }\end{array}$ & 0.5775 & 05 \\
\hline Reducing emissions & 0.5750 & 06 \\
\hline Usage of eco-friendly chemical & 0.5575 & 07 \\
\hline R\&D for product sustainability & 0.5500 & 08 \\
\hline Use sustainable raw materials & 0.5462 & 09 \\
\hline $\begin{array}{l}\text { Sustainable education } \\
\text { outreach }\end{array}$ & 0.5437 & 10 \\
\hline R\&D for process sustainability & 0.5387 & 11 \\
\hline Use renewable energy & 0.5062 & 12 \\
\hline Other tools (e.g. LCA*, DFE**) & 0.4975 & 13 \\
\hline Divert solid waste from landfill & 0.4900 & 14 \\
\hline Reducing chemical usage & 0.4888 & 15 \\
\hline Use 3rd party eco certification & 0.4137 & 16 \\
\hline
\end{tabular}

\section{DISCUSSION}

The purpose of the study was to find out the existing environmental manufacturing practices that are currently available in knit industries and assess their potentialities towards competitive outcomes. According to different available environmental practices, these practices are divided into two categories namely pollution prevention practices and product stewardship practices.

With few exceptions, pollution prevention practices seem to be consistently and robustly associated to decrease manufacturing cost and enhance company reputation. From the study it was found that, though divert solid waste from landfill practice was unanimously rejected as a source of cost reduction other practices support the outcome. As in knit industries, the solid wastes produced from operations go through several processes to be reused as a raw material so it has significant impact on cost reduction. Hence, these findings support Proposition 1 and are consistent with Hart ${ }^{1}$, who argues that the main competitive advantage yielded by pollution prevention practices is cost. Likewise, these findings are consistent with Porter and Van der Linde3, who argue that eliminating waste through practices like resource reduction and recycling can decrease costs. Enhancing company reputation is an outcome indicated as profoundly impacted from respondent's point of view. Reducing chemical usage and reduction of emission have greater impact over company reputation where reduction of raw material usage and divert solid waste from landfill have a moderate impact over this outcome. Herein the proposition 4 is robustly supported by the claim that, pollution prevention practices have significant impact on company reputation.

Other outcomes associated to proposition 2 and 3 are virtually ineffective by pollution prevention practices. With consistent to previous finding of Porter and Van der Linde ${ }^{3}$ the proposition 2 propose that productivity increases by the pollution prevention practices but, this empirical research shows that productivity doesn't increase significantly. The reasons are the practices include reducing emission, divert solid waste from landfill that clearly have no relation with productivity though reducing solid waste and reducing raw material usage have significant impact on proposition 2. Likewise, in proposition 3 described as employee morale and participation is increased by pollution prevention practices but in actual practice employee morale couldn't be increased by the practices included in pollution prevention practices because all the practices are generally related to manufacturing processes that don't have impact on the employee morale.

With little difference, product stewardship practices seem to be positively associated with competitive outcomes as measured by enhance company reputation, attracts new customer and promote innovative ideas by the company as indicated in the proposition 4,7 and 8 . While increasing company reputation product stewardship practices tend to increase customer attraction towards the firm. Stewardship practices like using other tools (e.g. LCA) and reducing chemical usages have a strong influence on customer attraction. Liability reduction is profoundly impacted by the pollution prevention practices indicated as in this empirical research but this outcome is classified in product stewardship practices in Veroutis. et $\mathrm{al}^{22}$. Innovative idea generation and promotion is a competitive outcome described in Porter and Van der Linde ${ }^{3}$ is also supported by the claim of product stewardship 
practices. Some product stewardship practices like use of $3^{\text {rd }}$ party eco-certification have poor impact on this regard. Product quality described as a competitive outcome in previously stated researches is regarded as a sustained competitive outcome but in this empirical research this claim couldn't be supported. Because, most of the practices are environmental consciousness related thus quality of product couldn't enhanced directly from product stewardship practices.

Though some of the relation were found positive and supported the previous studies where some were found irrelevant. This might be happened for various reasons for example this study was concerned with the knit industry of Bangladesh as no previous studies were on in this field.

\section{ACKNOWLEDGMENT}

Deepest gratitude goes to University Research Center of Shahjalal University of Science and Technology (SUST), Sylhet, Bangladesh, who has funded in this research work.

\section{CONCLUSION}

This study was conducted in the field of knitting industry of Bangladesh and its result has shown the positive relation between environmental manufacturing practices and competitive outcomes. Although there is a common myth that, practicing sustainability requires additional cost, but this study shows that company reputation, cost and other specific preemption outcomes (attracting new customers, promoting innovative ideas) are positively related to sustainability practices and they can provide competitive advantages.

The result of the study easily points out those environmental manufacturing practices that can give significant advantages to a company and competitive preemption. Moreover, result of this study rigorously supports the previous researches and also provide links to new outcomes that are adopted for knitting sector. In addition, this study was designed to avoid methodological limitations of previous studies that drew results from different industries that differs practices, by focusing only one industry. So the result of the study are very much conclusive in this perspective and such research is also important in the context of Bangladesh because its industrial sector is growing rapidly. This study is believed to shed light on the advantages of using environmental manufacturing practices.

At the firm level this study can also have great impact. Its result can encourage manufacturers to implement environmental manufacturing and harvest their advantages. This will not only give them a competitive edge on the market but can also improve their reputation as a green company which is very much valued now a day by customers, investors and stakeholders. Since some of the practices are very generic so its result can be used by other industry as well.

At the national or country level the environment of Bangladesh is continuously threatened by the industrial processes. In regard of conserving and protecting the environment many schemes are taken by many organizations and manufacturing industries can also easily help in such schemes by embracing environmental manufacturing practices that does not only contribute towards the protecting environment but also gives competitive base to a company in the market.

\section{REFERENCES}

1.S. L. Hart,1995, “A natural resource-based view of the firm,"Academy of Management Review, Vol. 20(4),pp. 986-1014.

2. D. W. Naffziger, N. U. Ahmed, and R. N. Montagno, 2003, "Perceptions of environmental consciousness in U.S. small businesses: An empirical study," SAM Advanced Management Journal, Vol. 68(2), pp. 23-32.

3. M. E. Porter and C. van der Linde, 1995, "Green and competitive: Ending the stalemate," Harvard Business Review, Vol. 73(5), pp. 120-134.

4.Annual Ready-Made Garment (RMG) Export of Bangladesh, Export Promotion Bureau, Bangladesh Bureau of Statistics,

http://www.epb.gov.bd/site/files/51916ae6-a9a3-462e -a6bd 9ef074d835af/Statistic - Data-2014-2015

(accessed: May 20, 2017

5. O. Mont, and A. Plepys, 2008, "Sustainable consumption progress: should we be proud or alarmed?" Journal of Cleaner Production, Vol. 16(4), pp. 531-537.

6. P. Bansal,2005, "Evolving sustainability: A longitudinal study of corporate sustainable development," Strategic Management Journal, Vol.26, pp. 197-218.

7. R. Frosch, and N. Gallopoulos,1989, "Strategies for manufacturing." Scientific American, vol. 261, pp. 144-152.

8. E. M. Snir, 2001, "Liability as a catalyst for product stewardship," Production and Operations Management, Vol. 10(2), pp. 190-206.

9. P. K. Freeman, 1994, "Integrating environmental risk into corporate strategy," Risk Management, Vol. 41(7), pp. 54-59.

10.W. Q. Judge, Jr. and H. Krishnan, 1994, "An empirical investigation of the scope of firm's

Journal of Mechanical Engineering, Vol. ME 48, December 2018

Transaction of the Mechanical Engineering Division, The Institution of Engineers, Bangladesh 
enterprise strategy," Business and Society, Vol.33(2), pp. 167-191.

11.N. U. Ahmed, R. V. Montagno, and R. J. Firenze, 1998, "Organizational performance and environmental consciousness: An empirical study," Management Decision, Vol. 36(2), pp. 57-62.

12.R. D. Klassen, and D. C. Whybark, 1999, "The impact of environmental technologies on manufacturing performance," Academy of Management Journal, Vol. 42(6), pp. 599-615.

13. P. Christmann, 2000, "Effects of "best practices" of environmental management on cost advantages: The role of complementary assets," Academy of Management Journal, Vol. 43(4), pp. 663-680.

14. R. S. Marshall, M. Cordano, and M. Silverman, 2005, "Exploring individual and institutional drivers of proactive environmentalism in the U.S. wine industry," Business Strategy Environment Vol. 14, pp. 92-109.

15.P. Shrivastava, 1995 "Environmental technologies and competitive advantage," Strategic Management Journal,Vol. 16, pp. 183-200.

16.B. Menguc and L. K. Ozanne, 2005, "Challenges of the "green imperative": A natural resource-based approach to the environmental orientation-business performance relationship," Journal of Business Research, Vol. 58(4), pp. 430-438.

17.I. J. Clelland, T. Dean, and T. Douglas, 2000, "Stepping towards sustainable business: An evaluation of waste minimization practices in U.S. manufacturing," Interfaces, Vol. 30(3), pp. 107-124.

18. C. Nehrt, 1996, "Timing and intensity of environmental investments," Strategic Management. Journal, Vol. 17, pp. 535-547.
19. C. Rusinko, 2007, "Green manufacturing: an evaluation of environmentally sustainable manufacturing practices and their impact on competitive outcomes" IEEE: Transactions on Engineering Management.Vol. 54, no. 03, pp. 445-454.

20. P. Ghemawat, 1986, "Sustainable advantage," Harv. Bus. Rev., Vol. 64(5), pp. 53-58.

21. M. Lieberman and D. Montgomery, 1988, "First mover advantages," Strategic Management Journal, Vol. 9, pp. 41-58.

22. A. D. Veroutis, A. L. Ullman, J. A. Fava, D. C. Steinmetz, and E. J. Kerfoot, 1996, "Competitive Advantage through Product Stewardship," Environmental Quality Management, Vol. 6(2), pp. 67-71.

23. R. J. Orsto, 2006, "Competitive environmental strategies: Whn does it pay to be green?" California Management Review,Vol. 48(2), pp. 127-143.

24. J. W. Johnson, and J. M. LeBreton, 2004, "History and Use of Relative Importance Indices in Organizational Research," Organizational Research Methods,Vol. 7, pp: 238-257.

25. Green revolution in Bangladesh apparel industry, http://www.dhakatribune.com/business/economy (accessed: July 25, 2017) 